\title{
Szabad és pásztoroló legeltetés intenzitásfüggő hatásai szikes vegetációban
}

\author{
Tóth Edina \\ MTA-DE Lendület Funkcionális és Restaurációs Ökológiai Kutatócsoport \\ 4032 Debrecen, Egyetem tér 1. \\ e-mail:toth.edina033@gmail.com
}

\begin{abstract}
Összefoglaló: A vizsgálatban hortobágyi rövid füvü szikes gyepekben vizsgáltam a legeltetés növényzetre gyakorolt hatásait. A mintaterületeket egyrészt pásztoroló magyar szürke szarvasmarha legeltetéssel kezelték (0,5-2,5 ÁE/ha), továbbá vizsgáltunk szabadon legeltetett $(0,1$ ÁE/ha) és túllegelt gyepterületeket (4 ÁE/ha) is. Kérdésem a következő volt: (i) Hogyan változik növekvő legelési intenzitás mellett a gyepek fajgazdagsága, funkcionális diverzitása és egyenletessége? Eredményeink szerint a legelési intenzitás nem volt szignifikáns hatással a fajgazdagságra; míg a Shannon diverzitás, az egyenletesség illetve a célfajok borítási értékei közepes legelési intenzitás mellett voltak a legmagasabbak. A legmagasabb Rao-féle kvadratikus diverzitási értékeket alacsony intenzitású, szabad legeltetés mellett kaptuk. Eredményeink alapján látható, hogy nagy funkcionális diverzitás eléréséhez az alacsony intenzitású legeltetés javasolt, azonban a nagy diverzitás és egyenletesség, valamint a célfajok magas borításának eléréséhez, a közepes legelési intenzitás szükséges.
\end{abstract}

Kulcsszavak: szabad legelés, pásztoroló legeltetés, szarvasmarha, intenzitás, fajgazdagság, egyenletesség, funkcionális diverzitás

\section{Bevezetés}

A nagy természetvédelmi értéket képviselő európai gyepterületek az utóbbi évtizedekben intenzívebbé váló mezőgazdasági gyakorlatnak, a megváltozott területhasználatnak, az urbanizációnak és a felhagyásnak köszönhetően jelentős mértékben megfogyatkoztak vagy degradálódtak (Deák et al. 2016, Dengler et al. 2014, Valkó et al. 2012). A fennmaradó gyepek megörzése ezért a hazai és nemzetközi természetvédelem egyik fö feladata. Ennek eszköze az alacsony intenzitású extenzív legeltetés alkalmazása (Dengler et al. 2014, Török et al. 2016). Hazánkban leginkább őshonos szarvasmarha fajtákkal történik a nagyobb kiterjedésü gyepi élőhelyek kezelése. A jó ellenálló képességü fajták alkalmazásának előnyeit, alkalmasságát eddig számos kutatás hangsúlyozta (Gilhaus et al. 2014, Metera et al. 2010, Török et al. 2014). 
A növényi tulajdonságokon, jellegeken alapuló vizsgálatok egyre elterjedtebbek (Kelemen et al. 2015, Teuber et al. 2013), és segítségükkel jobban megérthetjük a legelés hatásainak mögöttes mechanizmusait. A szerzett tapasztalatok megfelelő körültekintéssel beépíthetőek a gyepek természetvédelmi kezelési terveibe, azok hosszú távú megőrzése érdekében. A vizsgálat során a szarvasmarha legeltetés hatásait elemeztem, intenzitási gradiens mentén. A következő kérdésre kerestem választ: (i) Hogyan változik növekvő legelési intenzitás mellett a gyepek fajgazdagsága, funkcionális diverzitása és egyenletessége?

\section{Módszerek}

A kutatás során ürmös szikespuszta gyepek vegetációját vizsgáltuk, melyek a rövid füvű száraz gyepek hazai képviselői (Borhidi 2003). Az ürmös szikespuszta gyepeket föként legelőként hasznosítják hazánkban (Török et al. 2011), ahol a jellemző domináns füféle, a sovány csenkesz (Festuca pseudovina) rendkívül magas borítása, néhol akár a 70\%-ot is meghaladó mértékben (Kelemen et al. 2013, Lukács et al. 2015). A vizsgálati területek a Hortobágyi Nemzeti Park területén helyezkedtek el. A szabadon legelt területeken egész évben Heck szarvasmarhák illetve Pzrewalski lovak legeltek, alacsony 0,1 ÁE/ha intenzitással (3 terület). A hagyományos pásztoroló legeltetéssel kezelt területeken magyar szürke szarvasmarhával legeltettek, a legelési intenzitás szintjeit alacsony: 0,5 ÁE/ha, közepes: 1,5 ÁE/ha és magas: 2,5 ÁE/ha (intenzitásonként 3-3 terület) kategóriákba soroltuk. A hagyományos pásztoroló legeltetéssel kezelt, túllegeltetett területeken a legelö állatok magyar szürkemarha, juh és olykor szamár voltak, 4 ÁE/ha intenzitással (3 terület). A vizsgálatban elemzett legelési intenzitások összhangban voltak a helyi legeltetési rendszerekkel. A vizsgálat során elemeztem a legelés hatásait a gyepek célfajaira. Célfajok alatt olyan szikes gyepi specialista fajokat értendők, melyek megléte a kívánatos természetvédelmi állapot szempontjából igen fontos. Szikes gyepi közösségek esetén ezek föként a só-stresszhez jól adaptálódott halofiton fajok.

Az edényes növények borítási értékeinek becslésére 2014 májusának végén került sor, területenként tíz, $2 \times 2$ m nagyságú, 1ha területen egyenletes eloszlásban elhelyezett kvadrátban (összesen 150 kvadrát).

A kvantitatív növényi tulajdonságok esetében számoltam multi-trait indexeket: Rao-féle kvadratikus diverzitási indexet, funkcionális fajgazdagságot, funkcionális divergenciát és funkcionális egyenletességet, a súlyozáshoz Euklidészi távolság függvényt használtam. A vizsgált közösségekben számoltam fajszámot, Shannon diverzitást és egyenletességet. A számításokhoz FDiversity programcso- 
magot használtam (Casanoves et al. 2011). Összevetettem a gyepek vegetációs, valamint funkcionális tulajdonságait a legelési intenzitás különböző szintjei mellett, melyhez egyváltozós általános lineáris modellt (GLM) és Tukey-tesztet alkalmaztam SPSS 17.0 programban, ahol a "legelési intenzitás" volt a rögzített, és a "mintavétel helye" a véletlen faktor.

\section{Eredmények}

A vizsgálati területeken összesen 82 növényfaj jelenlétét mutattam ki. A fajgazdagság és a legelési intenzitás között nem találtam szignifikáns összefüggést $(\mathrm{F}=1,286 ; \mathrm{p}=0,278)$. Haranggörbe alakú összefüggést kaptunk a Shannon diverzitás $(\mathrm{F}=4,028 ; \mathrm{p}=0,004)$ és egyenletesség $(\mathrm{F}=5,092 ; \mathrm{p}=0,001)$ esetében növekvő intenzitási gradiens mentén. A vegetáció összborítása a növekvő legelési intenzitás mentén, az alacsony intenzitással kezelt területek kivételével, növekedett $(\mathrm{F}=26,242 ; \mathrm{p}<0,001)$. A célfajok borítása a közepes legelési intenzitás mellett volt a legmagasabb $(\mathrm{F}=31,929 ; \mathrm{p}<0,001)$.

A funkcionális gazdagság értékei nem tértek el a különböző intenzitással kezelt területeken $(\mathrm{F}=1,452 ; \mathrm{p}=0,220 ; 1$. táblázat). Viszont a legmagasabb Rao-féle kvadratikus diverzitási értékeket az alacsony intenzitással, szabadon legelt területeken mutattam ki $(\mathrm{F}=5,812 ; \mathrm{p}<0,001)$, az értékek növekvő intenzitás hatására folyamatosan csökkentek, kivéve a szabadon legelt területeken. A gyepterületek funkcionális egyenletessége $(\mathrm{F}=4,983 ; \mathrm{p}=0,001)$ közepes legeltetés mellett volt a legalacsonyabb, míg a funkcionális divergencia $(\mathrm{F}=5,304 ; \mathrm{p}=0,001)$ esetében mind közepes, mind nagyon magas intenzitás mellett alacsony értékek jelentek meg.

\section{Értékelés}

Eredményeink szerint a legelési intenzitás nem volt szignifikáns hatással a fajgazdagságra a vizsgált térléptéken, habár számos korábbi, legeléssel kapcsolatos tanulmány hangsúlyozza, hogy az alacsony intenzitású legeltetés általában növeli, míg a magas intenzitású legelés csökkenti a gyepek fajgazdagságát (Fischer \& Wipf 2002, Metera et al. 2010). A kapott eredményeket azzal magyarázom, hogy az általában fajszegény szikes gyepi közösségekben a legelés nem a fajkészletet, hanem a fajok borításának egymáshoz viszonyított arányát befolyásolta. A Shannon diverzitás és egyenletesség változását bemutató haranggörbe alátámasztja a közepes zavarási hipotézist (Connell 1978). Így a közösségek diverzitására és 
1. táblázat. Ürmös szikesek funkcionális és vegetációs növényi jellemzőinek alakulása a legelési intenzitás különböző szintjei mellett. Minden értéket súlyoztunk (átlag \pm SD). Megjegyzés*: csak folytonos változókra számolva. Egyváltozós GLM és Tukey teszt; a szignifikáns különbségeket félkövér betütípussal jelöltük.

\begin{tabular}{|c|c|c|c|c|c|c|c|}
\hline & \multicolumn{2}{|c|}{ Intenzitás hatása } & \multicolumn{5}{|c|}{ Intenzitás szintje } \\
\hline & $\mathrm{F}$ & $\mathrm{p}$ & Szabad & Alacsony & Közepes & Magas & Túllegelt \\
\hline & & & 0,1 áe/ha & 0,5 áe/ha & 1,5 áe/ha & 2,5 áe/ha & 4 áe/ha \\
\hline \multicolumn{8}{|l|}{ Multi-trait indexek } \\
\hline $\operatorname{Rao}^{*}\left(\times 10^{4}\right)$ & 5,812 & $<0,001$ & $\begin{array}{l}10,90^{\mathrm{A}} \\
\pm 1,57\end{array}$ & $\begin{array}{l}86,82^{\mathrm{B}} \\
\pm 2,40\end{array}$ & $\begin{array}{c}56,42^{\mathrm{AB}} \\
\pm 2,38\end{array}$ & $\begin{array}{c}49,05^{\mathrm{AB}} \\
\pm 1,50\end{array}$ & $\begin{array}{l}17,88^{\mathrm{A}} \\
\pm 8,46\end{array}$ \\
\hline $\begin{array}{c}\text { Funkcionális } \\
\text { fajgazdagság } *\left(\times 10^{8}\right)\end{array}$ & 1,452 & 0,220 & $\begin{array}{c}3,08 \\
\pm 1,04\end{array}$ & $\begin{array}{l}18,17 \\
\pm 1,03\end{array}$ & $\begin{array}{l}13,47 \\
\pm 8,94\end{array}$ & $\begin{array}{l}12,89 \\
\pm 1,39\end{array}$ & $\begin{array}{c}2,04 \\
\pm 8,38\end{array}$ \\
\hline $\begin{array}{l}\text { Funkcionális } \\
\text { egyenletesség* }\end{array}$ & 4,983 & 0,001 & $\begin{array}{l}0,39^{\mathrm{AB}} \\
\pm 0,20\end{array}$ & $\begin{array}{l}0,31^{\mathrm{AB}} \\
\pm 0,32\end{array}$ & $\begin{array}{l}0,25^{\mathrm{A}} \\
\pm 0,41\end{array}$ & $\begin{array}{l}0,39^{\mathrm{B}} \\
\pm 0,42\end{array}$ & $\begin{array}{l}0,38^{\mathrm{B}} \\
\pm 0,64\end{array}$ \\
\hline $\begin{array}{l}\text { Funkcionális } \\
\text { divergencia* }\end{array}$ & 5,304 & 0,001 & $\begin{array}{l}0,61^{\mathrm{AB}} \\
\pm 0,18\end{array}$ & $\begin{array}{l}0,61^{\mathrm{AB}} \\
\pm 0,28\end{array}$ & $\begin{array}{l}0,54^{\mathrm{A}} \\
\pm 0,32\end{array}$ & $\begin{array}{l}0,72^{\mathrm{B}} \\
\pm 0,38\end{array}$ & $\begin{array}{l}0,55^{\mathrm{A}} \\
\pm 1,08\end{array}$ \\
\hline \multicolumn{8}{|l|}{ Növényi jellemzök } \\
\hline Fajgazdagság & 1,286 & 0,278 & $\begin{array}{l}12,10 \\
\pm 3,79\end{array}$ & $\begin{array}{l}11,05 \\
\pm 6,44\end{array}$ & $\begin{array}{l}12,12 \\
\pm 6,29\end{array}$ & $\begin{array}{c}11,78 \\
\pm 12,60\end{array}$ & $\begin{array}{l}12,66 \\
\pm 8,28\end{array}$ \\
\hline Shannon diverzitás & 4,028 & 0,004 & $\begin{array}{l}1,33^{\mathrm{A}} \\
\pm 0,35\end{array}$ & $\begin{array}{l}1,42^{\mathrm{A}} \\
\pm 0,72\end{array}$ & $\begin{array}{l}1,70^{\mathrm{B}} \\
\pm 0,63\end{array}$ & $\begin{array}{l}1,56^{\mathrm{AB}} \\
\pm 1,08\end{array}$ & $\begin{array}{l}1,48^{\mathrm{A}} \\
\pm 1,24\end{array}$ \\
\hline Egyenletesség & 5,092 & 0,001 & $\begin{array}{l}0,54^{\mathrm{A}} \\
\pm 0,14\end{array}$ & $\begin{array}{l}0,60^{\mathrm{AB}} \\
\pm 0,29\end{array}$ & $\begin{array}{l}0,68^{\mathrm{B}} \\
\pm 0,20\end{array}$ & $\begin{array}{l}0,64^{\mathrm{AB}} \\
\pm 0,30\end{array}$ & $\begin{array}{l}0,59^{\mathrm{AB}} \\
\pm 0,51\end{array}$ \\
\hline Célfajok borítása & 31,929 & $<0,001$ & $\begin{array}{l}40,82^{\mathrm{BC}} \\
\pm 14,32\end{array}$ & $\begin{array}{l}41,30^{\mathrm{B}} \\
\pm 13,65\end{array}$ & $\begin{array}{l}69,36^{\mathrm{D}} \\
\pm 16,15\end{array}$ & $\begin{array}{l}51,07^{\mathrm{C}} \\
\pm 18,47\end{array}$ & $\begin{array}{l}25,25^{\mathrm{A}} \\
\pm 12,59\end{array}$ \\
\hline Összborítás & 26,242 & $<0,001$ & $\begin{array}{l}67,93^{\mathrm{A}} \\
\pm 14,90\end{array}$ & $\begin{array}{l}90,60^{\mathrm{c}} \\
\pm 15,18\end{array}$ & $\begin{array}{l}71,68^{\mathrm{A}} \\
\pm 19,26\end{array}$ & $\begin{array}{c}81,58^{\text {в }} \\
\pm 13,31\end{array}$ & $\begin{array}{l}89,83^{\mathrm{C}} \\
\pm 14,71\end{array}$ \\
\hline
\end{tabular}

egyenletességére volt hatása az intenzitásnak, melyet a közepes intenzitás mellett kapott legmagasabb értékek is alátámasztanak

Eredményeink szerint a közepes intenzitással legeltetett gyepekben találtam a legalacsonyabb funkcionális divergenciát és egyenletességet. Alacsony funkcionális egyenletességet általában az olyan közösségekben találunk, ahol az ökológiai fülkék (niche-k) kihasználtsága nem teljes, ami alacsony produkciót eredményez. Az alacsony funkcionális divergencia általában a niche differenciálódás alacsony szintjét eredményezi és nagyfokú erőforrás kompetíciót okozhat (Mason et al. 2005). A magas fajgazdagsággal párosuló alacsony funkcionális diverzitás lehetővé teszi a niche helyek jobb felosztását, lehetővé téve a hasonló funkcionális tulajdonságú fajok együttélését (Díaz \& Cabido 2001). Jelen tanulmányban arra a következtetésre jutottam, hogy a legmagasabb funkcionális diverzitás elérésére és a gyepi specialista fajok magas borításának fenntartásához az alacsony intenzi- 
tású szarvasmarha legeltetés alkalmas lehet. Azonban, ha a célfajok legmagasabb borítását, legmagasabb diverzitását és egyenletességét szeretnénk elérni, akkor közepes legelési intenzitás javasolt.

Köszönetnyilvánítás - A kutatás tárgyi és eszközfeltételeit támogatta és biztosította az MTA-DE Funkcionális és Restaurációs Ökológiai Kutatócsoport és a DE TTK Ökológiai Tanszéke. Köszönöm az MTA-DE Biodiverzitás Kutatócsoport munkatársainak segítségét, valamint az NKFI K 119225 pályázat anyagi támogatását.

\section{Irodalomjegyzék}

Báldi, A., Batáry, P. \& Kleijn, D. (2013): Effects of grazing and biogeographic regions on grassland biodiversity in Hungary - Analysing assemblages of 1200 species. - Agric. Ecosyst. Environ. 166: 28-34. doi: https://doi.org/10.1016/j.agee.2012.03.005

Borhidi, A. (szerk.) (2003): Magyarország növénytársulásai. - Akadémiai Kiadó, 610 p.

Casanoves, F., Pla, L., Di Rienzo, J. A. \& Díaz, S. (2011): FDiversity: a software package for the integrated analysis of functional diversity. - Methods Ecol. Evol. 2: 233-237. doi: https://doi. org/10.1111/j.2041-210X.2010.00082.x

Connel, J. H. (1978): Diversity in tropical rain forests and coral reefs. - Science 199: 1302-1310. doi: https://doi.org/10.1126/science.199.4335.1302

Deák, B., Tóthmérész, B., Valkó, O., Sudnik-Wójcikowska, B., Bragina, T.-M., Moysiyenko, I., Apostolova, I., Bykov, N., Dembicz, I. \& Török, P. (2016): Cultural monuments and nature conservation: The role of kurgans in maintaining steppe vegetation. - Biodivers. Conserv. 25: 2473-2490. doi: https://doi.org/10.1007/s10531-016-1081-2

Dengler, J., Janišová, M., Török, P. \& Wellstein, C. (2014): Biodiversity of Palearctic grasslands: A synthesis. - Agric. Ecosyst. Environ. 182: 1-14. doi: https://doi.org/10.1016/j.agee.2013.12.015

Díaz, S. \& Cabido, M. (2001): Vive la différence: plant functional diversity matters to ecosystem processes. - Trends Ecol. Evol. 16: 646-655. doi: https://doi.org/10.1016/S0169-5347(01)02283-2

Fischer, M. \& Wipf, S. (2002): Effect of low-intensity grazing on the species-rich vegetation of traditionally mown subalpine meadows. - Biol. Conserv. 104: 1-11. doi: https://doi.org/10.1016/ S0006-3207(01)00149-5

Gilhaus, K., Stelzner, F., Hölzel, N. (2014): Cattle foraging habits shape vegetation patterns of alluvial year-round grazing systems. - Plant Ecol. 215: 169-179. doi: https://doi.org/10.1007/ $\underline{\text { s11258-013-0287-6 }}$

Jerrentrup, J. S., Seither, M., Petersen, U. \& Isselstein, J. (2015): Little grazer species effect on the vegetation in a rotational grazing system. - Agric. Ecosyst. Environ. 202: 243-250. doi: https:// doi.org/10.1016/j.agee.2015.01.007

Kattge, J., Ogle, K., Bönisch, G., Díaz, S., Lavorel, S., Madin, J., Nadrowski, K., Nöllert, S., Sartor, K. \& Wirth, C. (2011): A generic structure for plant trait databases. - Methods Ecol. Evol. 2: 202-213. doi: https://doi.org/10.1111/j.2041-210X.2010.00067.x

Kelemen, A., Török, P., Valkó, O., Miglécz, T. \& Tóthmérész, B. (2013): Mechanisms shaping plant biomass and species richness: plant strategies and litter effect in alkali and loess grasslands. $-J$. Veg. Sci. 24: 1195-1203. doi: https://doi.org/10.1111/jvs.12027 
Kelemen, A., Török, P., Valkó, O., Deák, B., Tóth, K. \& Tóthmérész, B. (2015): Both facilitation and limiting similarity shape the species coexistence in dry alkali grasslands. - Ecol. Complex. 21: 34-38. doi: https://doi.org/10.1016/j.ecocom.2014.11.004

Király, G. (szerk.) (2009): Új Magyar Füvészkönyv. Magyarország hajtásos növényei. Határozókulcsok. - Aggteleki Nemzeti Park Igazgatóság, Jósvafö, 616 p.

Lukács, B. A., Török, P., Kelemen, A., Várbíró, G., Radócz, Sz., Miglécz, T., Tóthmérész, B. \& Valkó, O. (2015): Rainfall fluctuations and vegetation patterns in alkali grasslands - Self-organizing maps in vegetation analysis. - Tuexenia 35: 381-397. doi: https://doi.org/10.14471/2015.35.011

Mason, N. W. H., Mouillot, D., Lee, W. G. \& Wilson, J. B. (2005): Functional richness, functional evenness and functional divergence: the primary components of functional diversity. - Oikos 111: 112-118. doi: https://doi.org/10.1111/j.0030-1299.2005.13886.x

Metera, E., Sakowski, T., Słoniewski, K. \& Romanowicz, B. (2010): Grazing as a tool to maintain biodiversity of grassland - a review. - Anim. Sci. Pap. Rep. 28: 315-334.

Teuber, L. M., Hölzel, N. \& Fraser, L. H. (2013): Livestock grazing in intermountain depressional wetlands-effects on plant strategies, soil characteristics and biomass. - Agric. Ecosyst. Environ. 175: 21-28. doi: https://doi.org/10.1016/j.agee.2013.04.017

Török, P., Hölzel, N., van Diggelen, R. \& Tischew, S. (2016): Grazing in European open landscapes: How to reconcile sustainable land management and biodiversity conservation? - Agric. Ecosyst. Environ. 234: 1-4. doi: https://doi.org/10.1016/j.agee.2016.06.012

Török, P., Kapocsi, I. \& Deák, B. (2011): Conservation and management of alkali grassland biodiversity in Central-Europe. - In: Zhang, W. J. (Ed.): Grasslands: Types, Biodiversity and Impacts. Nova Science Publishers Inc., New York, pp. 109-118.

Török, P., Miglécz, T., Valkó, O., Tóth, K., Kelemen, A., Albert, Á., Matus, G., Molnár, V. A., Ruprecht, E., Papp, L., Deák, B., Horváth, O., Takács, A., Hüse, B. \& Tóthmérész, B. (2013): Seed weights support social behaviour types - analysis and new thousand seed weight records of the Pannonian flora. - Acta Bot. Hung. 55: 429-472.

Török, P., Tóth, E., Tóth, K., Valkó, O., Deák, B., Kelbert, B., Bálint, P., Radócz Sz., Kelemen, A., Sonkoly, J., Miglécz, T., Matus, G., Takács, A., Molnár, V. A., Süveges, K., Papp, L., ifj. Papp, L., Tóth, Z., Baktay, B., Málnási Csizmadia, G., Oláh, I., Peti, E., Schellenberger, J., Szalkovszki, O., Kiss, R. \& Tóthmérész, B. (2016): New measurements of thousand-seed weights of species in the Pannonian Flora. - Acta Bot. Hung. 58: 187-198.

Török, P., Valkó, O., Deák, B., Kelemen, A., Tóthmérész, B. (2014): Traditional cattle grazing in a mosaic alkali landscape: effects on grassland biodiversity along a moisture gradient. - PLOS One 9: e97095. doi: https://doi.org/10.1371/journal.pone.0097095 


\title{
Intensity dependent effects of free and pastoral grazing in alkali grassland vegetation
}

\author{
Edina Tóth \\ MTA-DE Lendület Functional and Restoration Ecology Research Group \\ 4032 Debrecen, Egyetem sqr. 1. \\ e-mail: toth.edina033@gmail.com
}

We studied the effects of grazing on short grass alkali grasslands vegetation. The study plots were grazed by traditional pastoral grazing of Hungarian Grey cattle (grazing intensities ranged from 0.5 up to 2.5 animal unit/ha), other plots were grazed by free grazing ( 0.1 animal unit/ha) and there were also further overgrazed plots (4 animal unit/ha). We set the following study question: (i) How do the grazing affect the species richness, functional diversity and evenness along an intensity gradient? We found no significant differences between in species richness of different intensity grazed plots, but Shannon diversity, evenness scores and cover of target species displayed a humped-shaped curve with a peak at medium grazing intensity. The highest Rao's quadratic entropy was found in low intensity free grazed plots. Our findings clearly suggest that for a high functional diversity a low intensity cattle grazing can be recommended, but for the highest diversity, evenness and cover of target species can be sustained by medium grazing intensity.

Keywords: free grazing, pastoral grazing, cattle, grazing intensity, species richness, evenness, functional diversity 